\title{
HAMP wt Allele
}

National Cancer Institute

\section{Source}

National Cancer Institute. HAMP wt Allele. NCI Thesaurus. Code C104272.

Human HAMP wild-type allele is located in the vicinity of $19 q 13.1$ and is approximately 3 $\mathrm{kb}$ in length. This allele, which encodes hepcidin protein, plays a role in both antimicrobial activity and iron homeostasis. Mutation of the gene is associated with hemochromatosis type $2 \mathrm{~B}$. 